\title{
Digital Contact Tracing Applications during COVID-19: A Scoping Review about Public Acceptance
}

\author{
My Villius Zetterholm ${ }^{1, *}$, Yanqing Lin ${ }^{2, *}$ and Päivi Jokela ${ }^{1}(0)$ \\ 1 Department of Informatics, Linnaeus University, Universitetsplatsen 1, 39231 Kalmar, Sweden; \\ paivi.jokela@lnu.se \\ 2 Department of Information and Service Management, Aalto University School of Business, Ekonominaukio 1, \\ 02150 Espoo, Finland \\ * Correspondence: my.villiuszetterholm@lnu.se (M.V.Z.); yanqing.lin@aalto.fi (Y.L.)
}

check for

updates

Citation: Villius Zetterholm, M.; Lin,

Y.; Jokela, P. Digital Contact Tracing Applications during COVID-19: A

Scoping Review about Public

Acceptance. Informatics 2021, 8, 48 .

https://doi.org/10.3390/

informatics 8030048

Academic Editors:

Guendalina Capece and

Flavia Di Costa

Received: 14 June 2021

Accepted: 19 July 2021

Published: 22 July 2021

Publisher's Note: MDPI stays neutral with regard to jurisdictional claims in published maps and institutional affiliations.

Copyright: (c) 2021 by the authors. Licensee MDPI, Basel, Switzerland. This article is an open access article distributed under the terms and conditions of the Creative Commons Attribution (CC BY) license (https:// creativecommons.org/licenses/by/ $4.0 /)$.

\begin{abstract}
Digital contact tracing applications (CTAs) have been one of the most widely discussed technical methods of controlling the COVID-19 outbreak. The effectiveness of this technology and its ethical justification depend highly on public acceptance and adoption. This study aims to describe the current knowledge about public acceptance of CTAs and identify individual perspectives, which are essential to consider concerning CTA acceptance and adoption. In this scoping review, 25 studies from four continents across the globe are compiled, and critical topics are identified and discussed. The results show that public acceptance varies across national cultures and sociodemographic strata. Lower acceptance among people who are mistrusting, socially disadvantaged, or those with low technical skills suggest a risk that CTAs may amplify existing inequities. Regarding determinants of acceptance, eight themes emerged, covering both attitudes and behavioral perspectives that can influence acceptance, including trust, privacy concerns, social responsibility, perceived health threat, experience of and access to technologies, performance expectancy and perceived benefits, and understanding. Furthermore, widespread misconceptions about the CTA function are a topic in need of immediate attention to ensure the safe use of CTAs. The intention-action gap is another topic in need of more research.
\end{abstract}

Keywords: COVID-19; contact tracing apps; technology acceptance; app adoption; app uptake; public attitudes; privacy; health technologies

\section{Introduction}

The year 2020 is doomed to be marked in human history by the worldwide outbreak of the COVID-19 pandemic. Among all the mitigation and control measures aiming at the socalled "flattening of the curve", such as enforced lockdowns, home confinement, and social distancing criteria, smartphone-based COVID-19 applications have emerged as one of the most frequently implemented technologies. Among these, contact tracing applications (CTAs) seem to be the most widely used technology, implemented in many countries striving to curb the pandemic spread [1,2]. CTAs are digitalized versions of contact tracing, a traditional and manual public health practice commonly deployed during infectious outbreaks as part of a track, trace, and isolation strategy [3,4]. The process of contact tracing is to track and identify an infected individual's contacts to break chains of transmission [3]. CTAs are smartphone-based applications that digitally track citizens' contacts by proximity to events or location, commonly using Bluetooth or GPS-based solutions. A robust CTA can theoretically be an effective strategy to curb the virus propagation by rapidly identifying and reporting contacts that are likely to have been infected by a patient carrying the virus [5,6]. In this vein, CTAs are underpinned by several assumptions, which are typically based on low false-negative and false-positive rates [3]. Generally, CTAs are capable of notifying individuals who have had contact with an infected individual, requesting them to quarantine and get tested $[1,7,8]$. CTAs are designed in various ways to collect and store 
different types of data and apply varying degrees of protection, which has implications for privacy as well $[9,10]$. From a technical standpoint, CTA systems architecture can be centralized or decentralized. In the former design, a central database and server store and process user data, whereas in the latter design, users' personal devices manage most of the data storing and processing, so that the central server plays only a minor role in the contact-tracking process [11]. Another important technical feature is what data sources are used for contact tracing; the standard design options are Bluetooth-based proximity data exchanged between phones when they are near each other and GPS-based location data to determine the phone's location and movements [12]. The third design decision concerns how much identifying data is stored in the central repositories if this data is secured with encryption or open and authorized to access the collected data [11-13].

Although both academia and public media hold the ground that CTAs theoretically can limit the spread of COVID-19 [7,14,15], critical voices have been raised against their introduction. Since the effectiveness of CTAs was estimated primarily based on modeling studies [14,16], the roll-out, seen in many countries during 2020, was not underpinned by empirical evidence supporting this approach. Apart from the call for more evidence of both accuracy and effectiveness [6], scholars have also argued that no pilot studies or risk assessments were published before massive roll-outs [17]. Furthermore, scholars in the information systems field have argued that apps have been designed with an all too narrow understanding of both transmission routes and social reality, such as travel patterns [18]. The emergence of these technologies has also raised concerns about privacy and security [19,20], as well as legal and ethical aspects [21-24]. Public acceptance is vital to motivate the roll-out and continued use of CTAs, both in terms of ethics [24] and effectiveness $[8,14,25]$. With this in mind, a better understanding of human-centered perspectives is critical for this type of emergent technology to be designed and used in an ethical, fair, and effective way. The World Health Organizations Strategic and Technical Advisory Group for Infectious Hazards has identified social acceptability for different preventive measures as a critical area in need of further research [26]. In that spirit, the current literature about CTAs and human perspectives typically attempt to address different factors that impact individual willingness to engage in contact tracing systems [25,27], as well as the differences between CTA specifications, individual user characteristics, and attitudes towards downloading or installing a CTA [28-30]. Although previous studies have investigated individual intention to adopt CTAs, there is a knowledge gap; no study comprehensively compiles and summarizes the rapidly emerging body of literature about CTA acceptance. A vast number of countries have now integrated CTAs into their deconfinement plans. However, the uptake remains low in many countries, in large part because we do not know enough about the determinants of uptake [6]. It is, therefore, a pressing need to gain a better understanding of the intended users of these systems and the factors that may facilitate or hinder the acceptance and adoption of CTAs across the world. This review responds to this gap by offering a comprehensive and holistic review of the field, and by analyzing and aggregating the scattered empirical findings across the world into themes, displaying common patterns to enable an emerging theoretical understanding of the determinants for CTA acceptance.

Digital technologies are becoming a fundamental part of public health work, and the practical implications of any successful pandemic prevention are considerable. COVID 19-pandemic infection and death rates may slow down in countries with robust vaccination coverage in the near future. However, on a global scale, this virus, new mutations, and new pathogens will continue to disrupt societies for ages to come [31,32]. It is therefore of great importance to continue the research in this field. Theoretically, research on CTAs can inform a broader, emerging field of technologies for epidemics and similar societal crises. Such technologies involve complex risk and benefit issues for the individual user [33], and they involve aspects of both prevention and surveillance. A current example of an up-and-coming technology that can benefit from such knowledge is the vaccination 
passports/immunity passports, which have been vividly discussed $[34,35]$ and recently proposed to be used within the European Union [36].

Accordingly, this scoping review strives to identify important resources, describe the current knowledge about public acceptance for COVID-19 CTAs, and further explore critical individual perspectives that may facilitate or hinder public acceptance and adoption of these systems. To this end, this study provides an overview of the field and type of research activities; it contributes with insights for further theory development and can guide researchers interested in the user perspectives of CTAs and related emerging technologies. The research questions that guided this work are:

- What type of research is available, and what is the current knowledge about variations in CTA acceptance?

- Which determinants can influence CTA acceptance and adoption?

In this study, we approach the area of CTA acceptance with a holistic perspective. As proposed by Schwartz and Chin [37], technology acceptance in this context can be understood as a user's psychological attitude, i.e., willingness or resistance to use, the user's understanding of the technology, and the behavioral interaction with an IT-artefact over time. With this in mind, we have reviewed studies that include empirical findings of users' attitudes, intention or motivation, understanding of the CTA technology, and adoption or discontinuation in practice. The study is delimited to reviewing empirical studies about individual perceptions about CTAs and does not cover any evidence about the preventive effect or technical perspectives on CTA design.

This paper is structured as follows: Section 2 presents the method, followed by the review findings in Section 3: Section 3.1 is an outline of the retrieved resources; Section 3.2 describes how public acceptance of CTAs varies concerning different cultures and individual characteristics; and Section 3.3 provides a thematic overview of the determinants of acceptance and adoption, focusing on individual perceptions and behaviors. Section 4 discusses the review findings and compares them with relevant literature and theoretical perspectives. The final section conclude this study and propose avenues for future research.

\section{Method}

A scoping literature review is conducted in the current study. This review type has emerged in the evidence synthesis field in the recent decade [38-40]. The scoping review has been well-acknowledged and valid for not only determining the coverage of a literature body on a given topic, but also giving clear specific indications concerning the volume of the available literature and an (either broad or detailed) overview of its focus [41]. The purpose of a scoping review is typically to provide a rapid overview of the extent and nature of the activities [38]. In other words, a scoping review is often undertaken to identify and map the available evidence to address such issues as research gaps, critical concepts, and theories $[38,42]$. Consequently, compared to a narrow systematic review, the scoping review allow for a broader scope and can be used to identify and discuss characteristics and key factors related to a phenomenon of interest [41]. It is a valuable methodology to give an overview and a sense of the fast-developing and cross-disciplinary topic covered in this paper. This scoping review applies the five-step methodology described by Arksey and O'Malley [38], including, in subsequent order: identifying research questions, identifying relevant studies, selecting appropriate studies, charting the data, and finally collating, summarizing, and reporting results.

This review examines the current literature concentrated on the acceptance and adoption of digital CTAs. The searches were conducted in two databases, namely Scopus and the core collection of Web of Science. The Scopus and Web of Science databases contain the most current research references and are, in turn, most frequently consulted by researchers and experts in different areas of knowledge [43]. Searches were also conducted in Google Scholar to identify additional relevant papers and grey literature (unpublished items such as preprints). From a practical standpoint, retrieval limitations had to be addressed at the outset, including the review scope regarding language, search fields, and time span, 
to name only a few. The inclusion criteria were set as journal or conference papers, including grey literature such as pre-prints. The topics of interest were empirical studies investigating the acceptance and adoption of CTAs, including attitudes and motivation or intention to download or use a CTA. Furthermore, only papers in English, available by open access or through our respective university accounts, were considered. Reflecting time and budget constraints, we included only those studies published after January 1st, 2020. Notably, the year 2020 was chosen as a start date because it covered the beginning of the worldwide COVID-19 pandemic. No limits were given for the geographic area or method used. Searches were conducted in January and the first two weeks of February 2021, with the stop date February 14th. Inquiries with the following keywords were carried out in all possible search fields (including title, abstract, keywords, and main text) in the two databases mentioned above and Google Scholar. The first and second authors conducted the searches. The following search terms were used:

- COVID-19/COVID/Coronavirus

- Applications/apps/contact tracing/digital contact tracing

- User/users perspective/public/attitude/adoption/intention to adopt/adoption intention/intention to use/acceptance

A total of 96 records were collected from Scopus and Web of Science. However, only 58 articles remained after dropping duplicates. In the next step, a first screening was conducted by reading titles and abstracts to sort out the irrelevant (outside the scope of the study) and non-empirical literature (viewpoint pieces, theoretical and review articles) from the empirical studies. In total, 15 papers were identified in these databases. In Google Scholar, the screening of findings was restricted to the first 30 search hits based on combinations of the search terms above. This provided us with 10 additional papers. As a result, we reached the final sample size of 25 empirical studies in this review. Figure 1 illustrates the flow diagram of the literature selection. The complete list of papers included in this review can be found in the Appendix A (Table A1).

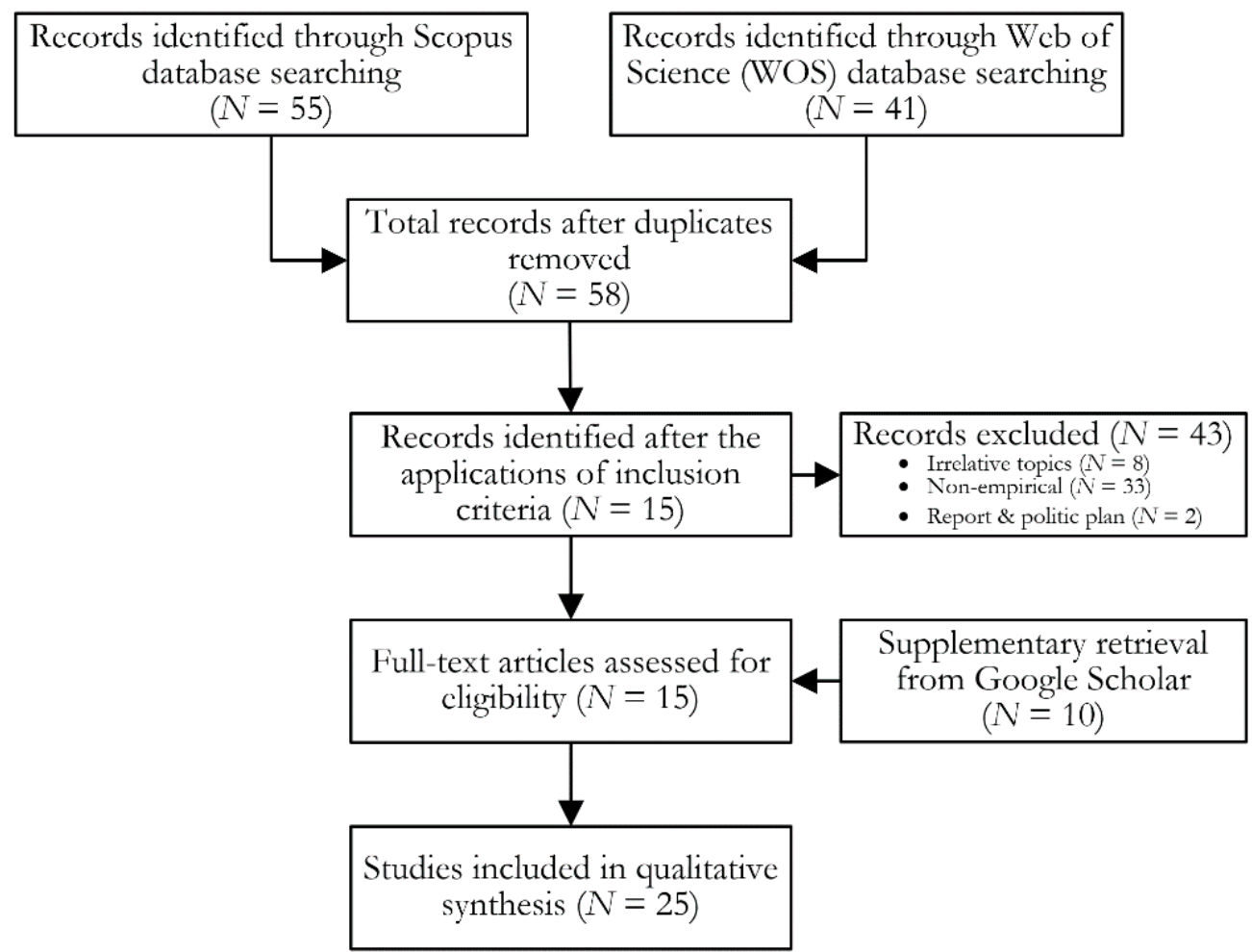

Figure 1. Procedural outline of literature selection. 
The retrieved papers were first read through, and key findings were charted to organize the findings. Only findings related to the research questions were extracted from the papers and included in this process. In the subsequent steps, the key findings were compared and described in a narrative way. The findings related to the second research question are presented as themes in Section 3.3. A narrative presentation with themes was chosen to synthesize both quantitative and qualitative findings [44] to compile related findings from the multidisciplinary pool of literature. Furthermore, a thematic presentation provides a higher level of abstraction, transferability, and overview of this complex field. In this process, related findings were grouped into categories and combined into overarching themes. One of the authors conducted the thematic analysis and critically assessed and discussed it with the other authors. This process was iterative, and themes were revised and merged to avoid overlaps.

\section{Review Findings}

\subsection{Outline of Retrieved Resources}

An overview of the empirical studies included in this review is presented in Appendix A. The selected 25 empirical papers in the current literature studied the acceptance and adoption of CTAs based on several traditional theoretical models. These theories included the Technology Acceptance Model (TAM) [25], Theory of Reasoned Action (TRA) [45], Theory of Planned Behavior (TPB) [45,46], Health Belief Model (HBM) [7], Protection and Motivation Theory [47], Cognitive Appraisal Theory [48], and Procedural Fairness Theory and Cultural Dimension Theory [46]. Demographics and personality traits are commonly investigated as well [25,49]. Most of the studies are questionnaire-based quantitative surveys, and there are also a few digital choice experiments. Three studies [48,50,51] are qualitative and explorative in their approach. Most studies are online surveys with non-randomized samples, typically conducted by recruiting companies or paid samples in survey panels. A few studies mention representative sampling (by demographics), while others include various forms of convenience or snowball sampling, e.g., the participants are recruited from social media, contacts, mail, or web pages.

From the perspective of cultural context, available studies primarily represent four continents. Studies from Europe covered Germany, France, Switzerland, United Kingdom, Italy, and the Netherlands. Asian studies focused on China (including the Taiwan region), and a few were conducted in South Korea and Jordan. Studies from North America primarily investigated the United States, and Oceania studies focused on Australia plus one study from Fiji Islands. None of the identified studies focused on individuals in Africa or South America. Generally speaking, most studies focus on attitudes, including individuals' willingness or intention to install a hypothetical CTA. Only a few provide evidence from real users and the uptake in practice, or a combination of actual use and intentions to use $[48,52-57]$.

\subsection{Variations in Acceptance Across Cultural Contexts and Individual Characteristics}

Public acceptance and willingness to download and/or use CTAs vary to a great extent, although the aspects that influence acceptance seem to be fairly similar. The latter is further elaborated upon in Section 3.3. Variations in acceptance are seen in different cultural contexts and in relation to individual characteristics, such as sociodemographic background and personality traits.

\subsubsection{Cultural Contexts}

Cultural background is typically associated with varying trust and acceptance of tracking technologies. To exemplify, the perceptions about privacy and the relation to attitudes or intentions to use CTAs seem to differ in countries with collectivist values, such as Fiji Island [46] and China [29]. Samples from Asian regions generally report higher acceptance [28,29,55]. Broad acceptance is also described in Australia [53], even though the adoption, in reality, seems lower, with approximately $37 \%$ stating that they 
have downloaded a CTA [56]. In comparison, the U.S. and European respondents generally report lower acceptance [29,57-59], even though the results vary greatly. The highest acceptance in Europe is seen in a large study (ca 8000 participants) from Ireland, with $84 \%$ reporting that they would definitely or probably download an app. It is worth noting that the sample was recruited through university channels and contacts, making this sample less representative of the general population [60]. Table 1 lists results from some of the key studies which provide percentages on the proportion of individuals finding the CTA technology acceptable by displaying positive attitudes or intention to use a CTA.

Table 1. Cultural variations.

\begin{tabular}{|c|c|c|}
\hline Cultural Context & Percentage of Individuals Displaying Acceptance * & Reference \\
\hline Asia & $71-90 \%$ & \\
\hline Mainland China & $80 \%$ & [29] \\
\hline Jordan & $71 \%$ & [52] \\
\hline Taiwan region & $>90 \%$ & {$[61]$} \\
\hline Europe & $38-84 \%$ & \\
\hline France & $38-42 \%$ & [58] \\
\hline Germany & $41 \%$ & [29] \\
\hline Netherlands & $59-66 \%$ & [59] \\
\hline Ireland & $84 \%$ & {$[60]$} \\
\hline Northern America & $39-59 \%$ & \\
\hline U.S. & $39-59 \%$ & {$[29,49]$} \\
\hline Multicultural studies & $54-75 \%$ & {$[25,26,52]$} \\
\hline
\end{tabular}

\subsubsection{Individual Characteristics}

In addition to the cultural contexts, various demographic characteristics, inherent personality-related factors, and individual attitudes to CTAs can impact individual acceptance of CTAs. Many of the existing studies have investigated the impacts of fundamental demographic factors on the willingness or intention to adopt CTAs [25,28,59]. Examples include age $[7,57,59]$ and gender $[25,29,62]$. In general, these studies associate younger ages with a positive attitude towards CTAs $[28,29,57,61]$. However, a more recent study in Germany showed that people over 50 are more likely to download a CTA [54]. Among the younger population, attitudes seem more important, and among the older people, technical concerns rather than attitudes can hinder uptake [57]. What is more, educational attainment [7,59], income situation [29], and the demographic living area [29] predict acceptance. Individuals with higher household income and higher education are more likely to adopt a CTA, as shown by multiple studies of uptake in practice [48,52-57]. Conversely, having an immigrant background seems to be associated with lower trust and lower uptake of CTAs [48,52-57]. It is worth noting that the city size can also positively contribute to such an app's adoption [29]. Furthermore, some studies investigate the association between personality traits and CTAs adoption. Pro-socialness [49] and innovativeness [25] have shown a positive relation to higher acceptance. In a large study on a U.S. sample, individual characteristics show to be more important than, for example, the privacy and security properties of the CTA [49]. Table 2 presents the most important individual characteristics and the key references. 
Table 2. Individual Characteristics.

\begin{tabular}{lc}
\hline Individual Characteristics & Reference \\
\hline Sociodemography & \\
\hline Age & {$[9,28,29,54,57,59,61,62]$} \\
\hline Gender & {$[25,28,29,62]$} \\
\hline Living area, language region & {$[29,52,57]$} \\
\hline Citizenship, Immigrant background & {$[52,57]$} \\
\hline Education & {$[7,49,52,60]$} \\
\hline Income & {$[29,49,52,57]$} \\
\hline Personality traits & {$[25,49]$} \\
\hline Innovativeness & {$[49]$} \\
\hline Pro-socialness & \\
\hline
\end{tabular}

\subsection{Determinants of CTA Acceptance and Adoption}

When compiling the literature from multiple cultural contexts, the following key themes describe the most current understanding of perceptions and behavior associated with CTA acceptance based on multiple studies across the globe: (1) Trust; (2) Privacy concerns; (3) Social responsibility; (4) Perceived health threat; (5) Experience of and access to technologies; (6) Performance expectancy and perceived benefits; (7) Understanding; (8) The intention-action gap.

\subsubsection{Trust}

Trust, together with trust-related factors, are mentioned in large part of the current literature across various countries and regions, which are associated with a high public acceptance either at an individual or national level $[28,29,47,57,58,63]$. Trust is exemplified as trust in the government or authorities $[29,48,51-58,63]$, trust in the healthcare system [57,63], trust in science [54], and trust in technology companies or apps developers [47]. Trust-related factors and political beliefs can also impact public acceptance of CTAs. Examples include conspiracy beliefs that can make people avoid contact tracing apps [29]. People with high acceptance of authoritarianism seem more accepting of digital surveillance technologies than those who value individual liberties, as shown in a study in Poland [62]. Similarly, political affiliation and beliefs about a legitimate government are associated with a positive attitude towards CTAs [64]. Adherence to other preventive measures (e.g., wearing masks) is also associated with CTA-uptake [48,52-57].

It is noteworthy that a high trust in authorities sometimes seems more important than privacy designs, security issues, or threats to individuals' autonomy. This can be exemplified by the high acceptance rates in Asian countries, as described in the previous sections. This is evident even though CTA solutions are more privacy-invasive in these countries. For example, trust in the government is high in the Chinese samples, where also the support for CTAs is the highest [29]. By contrast, fear of negative consequences such as government surveillance and privacy issues are more evident in Europe and the US, even though app designs are more privacy-protective in these countries $[29,58,59]$. In an Australian study of real uptake, distrust in the government was among the most important reasons for not using a CTA [56]. A noteworthy example illustrating the importance of trust is a study in the UK by Horvath et al. [63], where trust in their national health care system (NHS) is high. Participants in this study did not prefer decentralized designs as one could expect, as the attributes related to this kind of systems architecture are considered more privacy-preserving. Instead, the participants preferred a centralized model based on their national health service system and a combination of digital and human contact tracing. An NHS-based app was preferred over a government app. These preferences were not set aside even if the treatment group was prompted with extra data breach stimulus. 
Conclusions from this study include that trust in the app provider is more important than privacy concerns and design preferences [63]. High trust in the health care system and the government was also associated with downloading a CTA in a study of real users in Switzerland [57].

\subsubsection{Privacy Concerns}

Privacy concerns and related perceptions about data security are critical factors for accepting CTAs, as reported in many studies and various cultural contexts $[28,46,51,55]$. Security concerns include fear of data breaches or data misuse $[47,59]$, fear of hackers, or that data will be shared with third parties [50]. Privacy has been viewed as an ethical concern [52] and can cause a barrier to CTA adopting intention [7,46,47]. In Australia and Europe, privacy concerns have been reported as a significant barrier that prevents citizens from adopting contact tracing apps in practice as well [56,57]. Fear of surveillance from the government is expressed in numerous studies $[28,60]$, but privacy matters not only about the authorities. The identity of the app developer seems to matter [55], as well as privacy in relation to other individuals. Individuals have expressed fear of being stigmatized if personal information about a positive infection is shared with others $[48,50]$.

In a study conducted in the U.S. in 2020, Li et al. [49] found that known security and privacy risks that relate to different systems architectures and access to users' location data had a very small effect on users' adoption intentions general. However, the technical design preferences vary between different demographic groups and people with different individual characteristics. Individuals who are critical to CTAs seem to care even more about privacy perspectives [33]. When given a hypothetical choice, most individuals choose a privacy-preserving design over less privacy-preserving alternatives [55,59,61]. CTAs that include privacy-preserving features, such as non-location-tracking, Bluetooth technology, or decentralized data storage, can increase users' acceptance of contact tracing apps [29]. To counteract privacy and security concerns, it may also help provide potential users with assurance that their data will be handled safely. Bradshaw et al. [64] show that this type of assurance can positively impact individual intention to adopt a CTA. Similarly, individuals have expressed the importance of transparency and informed consent in relation to CTA implementation [55]. It should also be noted that the users, in general, may have difficulties fully understand how different technical designs affect their privacy and security [55]. Li et al. [49] indicated that even if the users did not explicitly prefer decentralized architecture, this choice could be derived from the result that the risk for secondary data use was the only concern that decreased the users' intentions to install CTA, and centralized architectures are more exposed to risk for secondary data use [49].

Privacy and security concerns are closely connected to trust (as elaborated in Section 3.3.1). For example, among individuals with lower trust in their government, privacy and security concerns are more pronounced [28]. This relationship seems to go both ways in contexts and among individuals where trust is high [46], privacy and security concerns, as well as privacy-protecting designs, seem to be less important [63].

\subsubsection{Social Responsibility}

Social responsibility and related moral ideas are expressed in multiple studies and cultural contexts. These perspectives are also closely interlinked with social norms and collectivism. For instance, the opportunity to help family and friends and a sense of responsibility to the community have been among the most reported and most important reasons for wanting to download a CTA in multiple studies $[28,46,60]$. The public health benefits have been identified as more important than perceptions of privacy and security risks in a large study in the U.S. [49]. In a study in Germany, social benefits were important to affect those who were critical to CTAs [33]. However, ideas about social benefits seem to be more pronounced among those who intend to use a CTA, as well as ideas about CTAs in relation to the greater good [50]. Similarly, in a multicultural study conducted by Simko et al. [55], many of the respondents could consider sharing information about a positive 
infection to the government or their app providers, even though they were reluctant to share other types of information. This finding indicates that moral obligations and the opportunity to protect others from infection can be important drivers. Such messages might motivate people to use a CTA and sway potential critics. However, a small study $(N=302)$ conducted in China has shown contrasting results, where no relation was found between moral norms and the intention to adopt a CTA. In this study, guidelines and epidemic knowledge had more importance than risk perceptions [45]. This study was conducted in universities and hospitals, indicating that high knowledge or high-risk settings may involve knowledge-based rather than moral factors.

\subsubsection{Perceived Health Threat}

Health-related aspects can include, for example, comorbidities, being at higher risk of severe COVID-19, having gone through a positive infection, or generally perceived health threat from COVID-19. Such research sample studies show some mixed results concerning CTA acceptance. In some results, perceived health threat is positively associated with acceptance. Moreover, people who state that they are not worried at all by COVID-19 have a lower intention to use a CTA $[29,54]$.

In the Netherlands, underlying health conditions have shown a weak relation to adopting a CTA [59], and, in a German study, perceived health threat showed no relation to the motivation to use a CTA [47]. Another German study [54] shows that uptake, in reality, is more common among those with a higher risk of getting severe COVID-19 due to age or pre-existing conditions. Nevertheless, uptake is lower among those at higher risk of getting infected by the virus due to habits, such as more social contacts with family and friends, more frequent public transportation, and lower adherence to other preventive measures. However, CTA adoption seems to be more common among individuals who have had a COVID-case in their social network [54]. Other risk-based factors, such as mortality rates in a country, showed no relation to the intention to use a CTA in the study by Altmann et al. [28]. In contrast to the notion that higher risk ought to be a motivating factor for the intention to use a CTA, it is reported that feelings of anxiety and aversion to information about infection might be a barrier for adoption to some individuals $[28,56]$. To summarize, perceived health threat can motivate some to use a CTA, but the evidence on this topic is mixed.

\subsubsection{Experience of and Access to Technologies}

Technology experience, previous habits, and competence-related aspects have been associated with acceptance or intention to use a CTA in multiple studies. The current literature indicates that factors about personal competency can impact people's willingness to use CTAs, including self-efficacy [7,46,47], personal capability [29], and technology readiness [49]. Experience in using other health apps [29] and higher smartphone use, in general, are associated with positive intentions to download a CTA [28]. In a study of actual users in Switzerland, Internet using experience and younger age are associated with a higher chance of downloading a CTA in practice [57]. Similarly, self-efficacy for app usage and perceived benefits decreases with age [7], which is critical to consider concerning the age and experience of digital technologies. Technical concerns or lack of access to a smartphone have been reported as a barrier for uptake in multiple countries, where real uptake has been studied, for example, in Australia [56] and Switzerland [57]. Jonker et al. [59] have identified potentially required out-of-pocket costs that can be negatively associated with individual adoption intention to contact tracing apps. This may contribute to digital divides due to economic reasons.

\subsubsection{Performance Expectancy and Perceived Benefits}

Personal expectations about the functionalities and efficacy of the app in controlling COVID-19 will work matter as well [7]; past studies contend that performance expectancy [25] and perceived effectiveness of contact tracing apps [29] positively contribute 
to the intention to use CTA. This is seen across multiple cultural contexts [29]. Conversely, concerns about uptake or a low expected adoption rate in society will also have a negative impact on the intention to adopt a CTA $[50,59]$. This is reasonable, as these systems need a sufficient uptake to be useful and effective. Similarly, perceived benefits are covered in many studies, where primarily social benefits stand out as a key driver for adoption. A few studies report on perceived personal benefits $[33,46]$, and this can be exemplified as "By using the app, you make an important contribution to your personal health" [33]. However, the idea of personal benefits is questionable. Contact tracing apps can be viewed as surveillance technology [48]. As a result, the process of contact tracing implies that a user is contacted after potential exposure to stop further transmission, implying that the user's social contacts will receive the main benefits. This may explain some of the mixed results around this topic. For example, Trang et al. [33] report how personal benefits seem to minimize the willingness to use a CTA among both critics and undecided. Social benefits, privacy protection, and convenience seem more important for this sample [33].

To complement the core contact tracing feature, some applications can involve additional features or benefits. For instance, one way to improve personal benefits is to offer monetary incentives. In a study by Munzert et al. [54], an experimental intervention with small monetary incentives significantly improved uptake in a German context. In other studies, individuals are asking for more information features [55], which potentially can provide more value to the individual user.

\subsubsection{Understanding}

Related to personal benefits, multiple studies report that individuals do not have an accurate understanding of CTAs regarding preventive functions, different technological concepts, and designs. Specifically, there seem to be widespread misconceptions about how these technologies work and what benefits or risks they pose to the individual user $[50,55,56]$. Simko et al. [55] report from a multinational study that many respondents display an inaccurate understanding of technical and legal concepts, as well as the functionality and accuracy of different technical CTA approaches. This has implications for their willingness to use CTAs. Misconceptions about the process of contact tracing and the basic idea behind a CTA are also expressed as ideas about individual benefits or protection. This can be exemplified by the idea that the app can lead to health benefits [33]. In a closer examination of this phenomenon, Thomas et al. [56] show that a majority of respondents in Australia had an incorrect understanding of how the CTA application works. For example, $72 \%$ believed that the app could detect and warn the user when infectious individuals are near, and many also thought it would provide guidance on whether they could safely leave their homes. Some thought it would inform them if they had COVID-19. Similar misconceptions were expressed in the study of Williams et al. [50] situated in the UK, where the most common misconception included that the CTA would provide the users with some sort of mapping of active infections in the area, so they would know where they could go and not.

\subsubsection{The Intention-Action Gap}

Perceptions aside, one of the most critical barriers for uptake seems to be the intentionaction gap. This is reported, for example, by Garrett et al. [53], from a more recent study on the uptake in Australia. In the current context, the intention-action gap implies that many may have a positive attitude or display the intention to use a contact tracing application. However, in reality, they do not take action by downloading, installing, or using it. Similar findings are evident in another study on actual uptake [56], where apathy or awaiting others were described as some of the barriers. The intention-action gap can further explain the differences seen between positive attitudes and high intention to adopt and the low uptake in reality e.g., [28]. 


\section{Discussion}

\subsection{Type of Available Research Studies}

The majority of the studies in this field are quantitative panel surveys, and merely two studies are qualitative and more explorative $[48,50]$. The lack of explorative studies is somewhat surprising, given the unique situation provided by the emerging contact tracing technologies and the pandemic context. However, some survey-based studies enable new perspectives and insights into the field by compiling free-text responses from survey participants $[28,60]$. Furthermore, most studies use online surveys to investigate general attitudes or intentions to install a CTA, often based on a hypothetical opportunity or different types of information. It is essential to keep in mind that hypothetical questions and intended uptake constitute relatively weaker evidence. The fact that many of the studies in this review only investigate attitudes is the main weakness of this scoping review. A few studies investigate real users or a context where individuals have been allowed to download this type of technology. This type of literature is emerging. It is worth noting that all online surveys, even if demographics, gender, or region stratify them, represent internet users, i.e., the samples probably consist of younger people who have a higher technology affinity than the general public. The non-randomized sampling techniques limit representativeness and possibilities to draw inferences about the results for the broader public. Nevertheless, by reviewing and compiling several studies from various parts of the world, some common themes emerge, contributing to the aggregated knowledge in this field.

\subsection{Current Knowledge about Public Acceptance and Adoption of CTAs}

\subsubsection{Variations in Acceptance}

Factors influencing public acceptance and willingness to download and/or use CTAs are similar in many countries, although the relative importance of, e.g., privacy concerns, vary across different cultural contexts. This variation can probably be partly explained by cultural norms, such as collectivism, social responsibility, and authoritarianism, reflecting perceptions of the normative relation between individuals, their social context, and the government. Cultural background is generally associated with varying trust and acceptance of tracking technologies $[28,29,55]$, where samples from Asian countries show somewhat higher acceptance. It is noteworthy that privacy and security concerns are more pronounced in, e.g., Europe and the U.S., despite that existing CTAs tend to have a more privacy-protective design in these countries [29]. Existing studies convey that collectivism directly increases the adopting intention of a contact tracing app [46]. Concretely, in a society with high collectivism, the relationship between privacy concerns and the positive attitude to a tracing app can be weakened, thereby increasing adoption intention.

Furthermore, CTA acceptance varies based on personality traits and across the sociodemographic characteristics. The most noteworthy examples are age, living area, higher education and income, and relatedly, the experience of and access to technologies. These aspects are generally linked with higher acceptance and uptake of CTAs [29,52,54,57]. In contrast, having an immigrant background is associated with lower uptake of CTAs and lower trust [57]. Similarly, these sociodemographic differences and perceptions have been associated with adherence to preventive measures during previous pandemics [65] and acceptance of preventive technologies such as vaccines $[57,66]$. Of note, social exclusion, lower income and education, higher age, and immigrant background are already risk factors for COVID-19. In addition, unequal access to smartphones and varying digital literacy may increase the existing inequities and exacerbate health disparities [54]. Such findings indicate that cultural and sociodemographic factors need to be taken into account even before the design phase starts. These perspectives need to guide the requirements and potential costs for hardware, for example, whether smartphones are the most suitable tool, whether hardware should be subsidized, what type of support users might need, and how to implement this type of technology in different communities. 


\subsubsection{Determinants of Acceptance}

Eight themes emerged as important for the acceptance and uptake of CTAs: Trust, Privacy concerns, Social responsibility, Perceived health threat, Experience of and access to technologies, Performance expectancy and perceived benefits, Understanding, and Intention-action gap. Some of these findings are in line with findings in a rapid review focusing on engagement in contact tracing efforts. Specifically, mistrust has been shown to be an essential barrier for engaging in manual contact tracing [27].

The thematic overview presented in this study shows that the determinants influencing CTA acceptance are similar to some of the constructs found in existing theoretical models. For example, perceived severity, susceptibility, and self-efficacy found in HBM [67]; performance expectancy found in the Unified Theory of Acceptance and Use of Technologies (UTAUT) [68]; and perceived usefulness found in TAM [69]. However, the current review also shows that aspects, which are not covered in the existing theoretical models, are important for accepting this type of preventive technology. These include moral and cultural perspectives, such as social responsibility, trust, and privacy concerns, which seem to be among the most critical determinants for acceptance.

This study supports the notion that technology acceptance needs to be understood from a holistic perspective [37]. Except for the cultural context and individual characteristics, CTA acceptance and adoption are influenced by attitudes, behavioral perspectives, and the understanding (or misunderstanding) of the technology. Notably, the findings related to misconceptions require more attention. A faulty mental model about these technologies can have many consequences. Misunderstanding the risks and benefits of different designs can impact the acceptance and the use of CTAs. Furthermore, misconceptions about their preventive function may, in the worst case, lure users into a false safe of safety. This indicates that better information is needed about how the CTA works, the purpose of this kind of technology, the process of contact tracing, and, relatedly, its limitations.

What is more, many of the early studies in this review showed that individuals had a relatively high willingness to adopt these technologies [28]. In comparison, the uptake in practice has been lower in many countries $[6,18]$. The intention action-gap is probably among the most significant barriers to high uptake in countries where CTAs are voluntary. Pre-installed choices have been created (e.g., the Apple and Google version) to overcome this barrier. That said, some studies report that pre-installed alternatives are not as preferable as voluntary downloads [28]. In this vein, the appropriate balance between voluntariness and how to overcome the barrier with intention-action gaps deserves further research.

\subsection{Theoretical Contributions}

The findings presented in this paper can contribute to insights for further theory development and guide researchers interested in the user perspectives of CTAs and related emerging technologies. The theoretical relevance of this topic is essential from many perspectives. First, the nature of CTAs and the conditions for public acceptance significantly differ from other types of technologies, and health apps as the context of use and structure of benefits are unique [33]. As previously noted, there are not many benefits for the individual user within the core contact tracing mechanism since the chain of transmission is broken in the subsequent step. Second, the COVID-19 pandemic might slow down in certain countries with emerging vaccination coverage. Nevertheless, this virus, new mutations, and new pathogens will continue to disrupt societies on a global scale [31,32]. It is therefore of great importance to continue the research on preventive technologies. Third, this topic can contribute to a broader area of technologies and preventive strategies in situations that pose threats to society when joint efforts and broad acceptance are essential. Similar to CTAs, other preventive technologies require mass acceptance, which may balance individual conveniences and risks, individual liberty and the protection of others. Vaccination efforts and personal protective equipment are examples from the pandemic context. Symptom checkers and immunity passports are examples of emerging 
information technologies used for pandemic prevention. In contexts and situations where such technologies are motivated and can be introduced in ethical, fair and safe way, these areas can benefit from the knowledge produced in the CTA field as well.

\section{Conclusions}

This study aims to identify critical resources that describe the current knowledge about public acceptance for COVID-19 CTAs and explore individual perspectives that may influence the acceptance and adoption of these systems. The results show that a fair amount of empirical studies covering public attitudes are found in this area, and the research is steadily increasing. The majority of studies are observational in the format of quantitative online surveys. Many focus on hypothetical choices or individual motivations or intention to use CTAs, while literature covering uptake in practice is also emerging. Moreover, the current literature indicates that the cultural context affects acceptance. Collectivism and trust are beneficial, while CTA acceptance is more challenging in countries with lower trust and acceptance for surveillance. For instance, CTAs are generally more accepted in Asian countries than in the US and Europe, irrespective of privacy designs. In addition, at the individual level, CTAs are less accepted among individuals with lower income and education levels, among immigrants, and those mistrusting authorities. These findings align with previous literature on other preventive health behaviors and acceptance of preventive technologies, such as vaccinations. It is important to continue observing and addressing this type of division to avoid further deepening existing inequalities in health.

Furthermore, the study explored determinants that can influence CTA acceptance and adoption. Eight themes were generated on this topic: (1) Trust; (2) Privacy concerns; (3) Social responsibility; (4) Perceived health threat; (5) Experience of and access to technologies; (6) Performance expectancy and perceived benefits; (7) Understanding; and (8) The intention-action gap. This thematic analysis can provide a foundation for further theory development.

To conclude, to gain public acceptance of CTAs, individuals need to trust the operators that their data is kept safe and only used for infection control. Besides, they need to have access to and competence in using mobile devices, to understand and believe in the potential benefits of the technology and be motivated to contribute to the greater good. Moreover, individuals might need cues for action or pre-installed alternatives to lower the behavioral threshold. To avoid a false sense of protection, it is imperative that users understand and are clearly informed about the $\mathrm{CT}$ process and the limitations of the CTAs as a preventive technology. Users' understanding, adherence, and active use of CTAs correctly are ultimately as crucial as high uptake to ensure that contact tracing efforts reach the goal of minimizing infections.

There are many topics in need of more research within this rapidly emerging field. In addition to evaluating the effectiveness of CTAs, different designs and ethical and legal aspects, more knowledge about the human perspectives is still needed. First, methodologically, future survey studies can focus on choices on actual uptake. More field experiments in real settings, like Munzert et al. [54], are expected to generate stronger evidence on causal factors and effective interventions in this field. Second, considering CTAs as emerging technologies used in a unique context, explorative and qualitative inquiries are needed to improve understanding of the user perspectives. Likewise, more in-depth studies are needed to investigate adoption and discontinuation in practice and users' experiences and adherence when receiving an exposure notification from a CTA. Third, users' understanding and misconceptions of the technology and the contact tracing process need to be better addressed. Furthermore, the intention-action gap is probably among the most critical barriers for uptake in countries where CTAs are voluntary. This issue needs further research, including how to provide preventive technologies in a convenient and ethical way. 
Author Contributions: Project administration: M.V.Z., Conceptualization: M.V.Z., Y.L., Investigation: M.V.Z., Y.L., Methodology: Y.L., M.V.Z., Formal analysis: M.V.Z., Writing—original draft preparation: M.V.Z., Y.L., Writing—review and editing: M.V.Z., Y.L., P.J., Visualization: Y.L. All authors have read and agreed to the published version of the manuscript.

Funding: This research received no external funding.

Institutional Review Board Statement: Not applicable.

Informed Consent Statement: Not applicable.

Conflicts of Interest: The authors declare no conflict of interest. 


\section{Appendix A. Empirical Studies Included in the Review}

Table A1. List of all the empirical studies $(N=25)$ included in the present scoping literature.

\begin{tabular}{|c|c|c|c|c|c|}
\hline Study & Focus & Context & Sampling & Data Analysis Procedure & Key Factors Associated with Acceptance \\
\hline$[7]$ & $\begin{array}{l}\text { Predictors for intentions to } \\
\text { use a CTA (Contact Tracing } \\
\text { Application) }\end{array}$ & Belgium & $\begin{array}{l}\text { Online Survey }(N=1500) \\
\text { respondents aged } 18 \text { to } \\
64 \text { years }\end{array}$ & $\begin{array}{l}\text { Descriptive analysis; } \\
\text { structural equation modeling }\end{array}$ & $\begin{array}{ll}\text { - } & \text { Perceived benefits } \\
\text { - } & \text { Perceived barriers } \\
\text { - } & \text { Cues to action } \\
\text { - } & \text { Self-efficacy } \\
\text { - } & \text { Age }\end{array}$ \\
\hline [25] & $\begin{array}{l}\text { Predictors for the intention to } \\
\text { use a CTA }\end{array}$ & Belgium & $\begin{array}{l}\text { Online survey }(N=1500) \\
\text { respondents aged } 18 \text { to } \\
64 \text { years }\end{array}$ & $\begin{array}{l}\text { Descriptive analysis; } \\
\text { structural equation modeling }\end{array}$ & $\begin{array}{ll}\text { - } & \text { Performance expectancy } \\
\text { - } & \text { Effort expectancy } \\
\text { - } & \text { Social influence } \\
\text { - } & \text { Facilitating conditions } \\
\text { - } & \text { Annovativeness } \\
& \text { App-related privacy concerns }\end{array}$ \\
\hline [28] & $\begin{array}{l}\text { User acceptability of CTAs in } \\
\text { countries hit by COVID-19 } \\
\text { Intentions to use a CTAs in } \\
\text { voluntary vs. automatic } \\
\text { installation regimes }\end{array}$ & $\begin{array}{l}\text { U.S., UK, France, Germany, } \\
\text { and Italy }\end{array}$ & $\begin{array}{l}\text { Online survey }(N=5995) ; \\
\text { Respondents from panel } \\
\text { service, representative } \\
\text { sampling by demographic } \\
\text { distribution and offline } \\
\text { control group from Germany }\end{array}$ & $\begin{array}{l}\text { Descriptive analysis; } \\
\text { multivariate regression } \\
\text { analysis }\end{array}$ & $\begin{array}{ll}\text { - } & \text { Trust in government } \\
\text { - } & \text { Cybersecurity and privacy concerns } \\
& \text { Anxiety \& aversion to information about } \\
\text { - } & \text { Protect family \& friends } \\
\text { - } & \text { Responsibility towards the community } \\
\text { - } & \text { Stop the epidemic } \\
\text { - } & \text { Level of phone use }\end{array}$ \\
\hline
\end{tabular}


Table A1. Cont.

\begin{tabular}{|c|c|c|c|c|c|}
\hline Study & Focus & Context & Sampling & Data Analysis Procedure & Key Factors Associated with Acceptance \\
\hline [29] & $\begin{array}{l}\text { Public perceptions of CTAs } \\
\text { and factors affecting the } \\
\text { support }\end{array}$ & China, Germany, and the U.S. & $\begin{array}{l}\text { Online survey }(N=6464) \text {; } \\
\text { respondents were recruited } \\
\text { from a Berlin-based } \\
\text { survey firm. }\end{array}$ & $\begin{array}{l}\text { Ordered logistics regression } \\
\text { analysis }\end{array}$ & 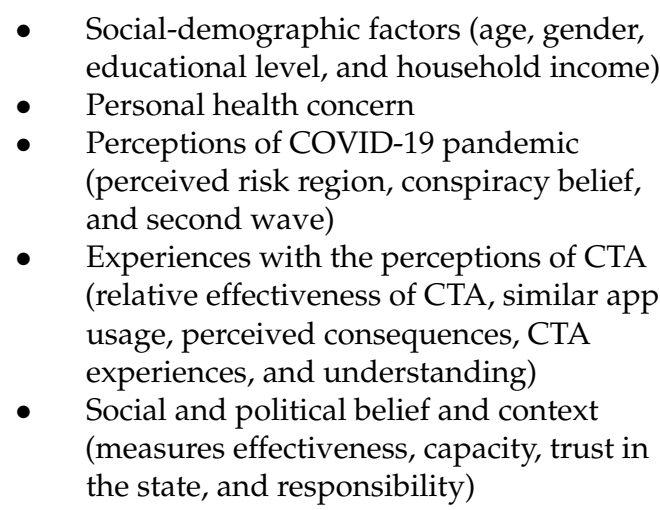 \\
\hline [33] & $\begin{array}{l}\text { Experimental study } \\
\text { investigating how the } \\
\text { intention to install a CTA is } \\
\text { influenced by different } \\
\text { appeals and app designs }\end{array}$ & Germany & $\begin{array}{l}\text { Factorial experiment } \\
(N=518) \text {; participants were } \\
\text { recruited for a nominal } \\
\text { payment through } \\
\text { Clickworker. }\end{array}$ & $\begin{array}{l}\text { Ordinary least squares (OLS) } \\
\text { regression; quantile } \\
\text { regression }\end{array}$ & $\begin{array}{ll}\text { - } & \text { Self-Benefit Appeal } \\
\text { - } & \text { Self-Societal-Benefit Appeal } \\
\text { - } & \text { High Privacy Design } \\
\text { - } & \text { Gener Convenience Design } \\
\text { - } & \text { Coronavirus Anxiety } \\
\text { - } & \text { IT Self-Efficacy } \\
\text { - } & \text { Demography (gender and age) }\end{array}$ \\
\hline [45] & $\begin{array}{l}\text { Perception-based influence } \\
\text { factor of individuals' } \\
\text { intention to adopt COVID-19 } \\
\text { epidemic prevention }\end{array}$ & China & $\begin{array}{l}\text { Online Survey }(N=302) ; \\
\text { respondents from } 6 \\
\text { universities and two } \\
\text { hospitals in China via } \\
\text { WeChat-based groups. }\end{array}$ & $\begin{array}{l}\text { Statistical analyses; path } \\
\text { analysis }\end{array}$ & $\begin{array}{ll}\text { - } & \text { Risk perception } \\
\text { - } & \text { Epidemic knowledge } \\
\text { - } & \text { Perceived feasibility to adopt epidemic } \\
& \text { prevention } \\
\text { - } & \text { Perceived behavioral control } \\
\text { - } & \text { Subjective norms } \\
\text { - } & \text { Risk aversion } \\
\text { - Governments' guidelines on epidemic } \\
\text { prevention }\end{array}$ \\
\hline
\end{tabular}


Table A1. Cont.

\begin{tabular}{|c|c|c|c|c|c|}
\hline Study & Focus & Context & Sampling & Data Analysis Procedure & Key Factors Associated with Acceptance \\
\hline [46] & $\begin{array}{l}\text { Explanatory study focusing } \\
\text { on factors influencing } \\
\text { willingness for CTA adoption }\end{array}$ & Fiji Islands & $\begin{array}{l}\text { Online survey }(N=714) \text {; } \\
\text { randomized sampling from a } \\
\text { COVID-awareness group on } \\
\text { Facebook. }\end{array}$ & Structural equation modeling & $\begin{array}{ll}\text { - } & \text { Perceived effectiveness of privacy policy } \\
\text { - } & \text { Privacy concerns } \\
\text { - } & \text { Perceived vulnerability } \\
\text { - } & \text { Expected privacy self-efficacy } \\
\text { information } \\
\text { - } & \text { Expected community-related outcomes of } \\
\text { - } & \text { sharing information } \\
\text { - } & \text { Cultudural background (collectivism or } \\
\text { - } & \text { Subividualism) } \\
\text { - } & \text { Privactive norms self-efficiency }\end{array}$ \\
\hline
\end{tabular}

Explanatory study

investigating cognitive

[47] factors relation to the

motivation for social

distancing, app use and

providing health data.
How people appraise the use of contact tracing apps

[48] during the novel coronavirus

(COVID-19) pandemic in

South Korea.
Online survey $(N=406)$

German-speaking

participants
Bivariate correlations,

multiple regression analyses
- Severity of infection

- Self-efficacy regarding social distancing

- Response efficacy of social distancing

- Response costs of social distancing

- Trust in other people's social distancing behavior

- Severity of data misuse

- Vulnerability to data misuse

- General trust in official app providers
Interviews $(N=25)$; nine

office workers, seven college

students, six housewives, and

three freelancers who had

used contact tracing apps for

COVID-19.

Survey $(N=506)$; users of

the apps
- Perceived threads (privacy intrusion, mental distress, misinformation, system quality)

- $\quad$ Perceived opportunities (speedy access to information, push notification, risk

(ATLAS.ti); hierarchical

regression analysis perception, prevention effectiveness)

- Emotions (challenge, loss) 
Table A1. Cont.

\begin{tabular}{|c|c|c|c|c|c|}
\hline Study & Focus & Context & Sampling & Data Analysis Procedure & Key Factors Associated with Acceptance \\
\hline [49] & $\begin{array}{l}\text { The Influence of App Design } \\
\text { and Individual Difference on } \\
\text { Contact-Tracing App } \\
\text { Adoption Intention }\end{array}$ & U.S. & $\begin{array}{l}\text { Choice experiment, online } \\
\text { survey }(N=1963) ; \\
\text { participants were recruited } \\
\text { using a Qualtrics panel. }\end{array}$ & $\begin{array}{l}\text { Linear regression analysis; } \\
\text { mediation analysis. }\end{array}$ & $\begin{array}{ll}\text { - } & \text { Pro-socialness } \\
\text { - } & \text { Technology readiness } \\
\text { - } & \text { General privacy concern } \\
\text { - } & \text { Demographic factors (gender, household } \\
\text { - } & \text { Design choices } \\
\text { - } & \text { Location use } \\
\text { - } & \text { App provider } \\
\text { - } & \text { Security risk presentation } \\
\text { - } & \text { Perception of the public health benefits } \\
\text { - } & \text { Perfered by the app } \\
& \text { privacy risks }\end{array}$ \\
\hline$[50]$ & $\begin{array}{l}\text { Explore public attitudes to a } \\
\text { CTA in the UK. }\end{array}$ & UK & $\begin{array}{l}\text { Online focus group } \\
\text { interviews }(N=27) ; \\
\text { participants were adults aged } \\
18 \text { years or over currently } \\
\text { residing in the UK. }\end{array}$ & Thematic approach & $\begin{array}{l}\text { - Lack of information and misconceptions } \\
\text { surrounding COVID-19 contact } \\
\text { tracing apps } \\
\text { - } \quad \text { Concerns over privacy } \\
\text { - } \quad \text { Concerns over stigma } \\
\text { - Concerns over uptake } \\
\text { - Contact tracing as 'the greater good' }\end{array}$ \\
\hline [51] & $\begin{array}{l}\text { The early perceptions of } \\
\text { digital contact tracing apps }\end{array}$ & $\begin{array}{l}\text { Germany, Austria, and } \\
\text { Switzerland }\end{array}$ & $\begin{array}{l}\text { Qualitative Interviews } \\
(N=159) ; \text { participants were } \\
\text { recruited through online } \\
\text { advertisement via university } \\
\text { websites, social media } \\
\text { networks, convenience } \\
\text { sampling, and snowballing. } \\
\text { Content Analysis of } \\
\text { Newspaper Coverage } \\
(N=194) ; \text { articles published } \\
\text { in quality newspapers } \\
\text { between March } 15 \text { and } \\
6 \text { May } 2020\end{array}$ & $\begin{array}{l}\text { Descriptive analysis; content } \\
\text { analysis }\end{array}$ & $\begin{array}{ll}\text { - } & \text { Trust in authorities } \\
\text { - } & \text { Respect for individual privacy } \\
\text { - } & \text { Voluntariness } \\
\text { - Temporary use of contact tracing apps }\end{array}$ \\
\hline
\end{tabular}


Table A1. Cont.

\begin{tabular}{|c|c|c|c|c|c|}
\hline Study & Focus & Context & Sampling & Data Analysis Procedure & Key Factors Associated with Acceptance \\
\hline [52] & $\begin{array}{l}\text { Acceptability of COVID-19 } \\
\text { contact-tracing technology } \\
\text { and ethical issues of use }\end{array}$ & Jordan & $\begin{array}{l}\text { Online Survey }(N=1654) \text {; } \\
\text { Convenience sample of } \\
\text { adults from the general } \\
\text { public via email \& } \\
\text { social media. }\end{array}$ & $\begin{array}{l}\text { Descriptive analysis; multiple } \\
\text { regression }\end{array}$ & $\begin{array}{l}\text { Ethical concerns (privacy, voluntariness, } \\
\text { and beneficence of the data) } \\
\text { - Income } \\
\text { - living area }\end{array}$ \\
\hline [53] & $\begin{array}{l}\text { Attitudes vs. real-world } \\
\text { usage towards three } \\
\text { technologies }\end{array}$ & Australia & $\begin{array}{l}\text { Survey }(N 1=1275 ; N 2=1777 ; \\
N 3=597 ; N 4=596) ; \\
\text { representative sample of the } \\
\text { Australian public stratified by } \\
\text { gender, age, and state per the } \\
2016 \text { census from Dynata. }\end{array}$ & $\begin{array}{l}\text { Descriptive analysis; } \\
\text { bayesian ordinal probit } \\
\text { regressions }\end{array}$ & $\begin{array}{ll}\text { - } & \text { Perceived risk from COVID-19 } \\
\text { - } & \text { Perceived benefits from tracking } \\
\text { - } & \text { Perceptions of tracking technologies }\end{array}$ \\
\hline [54] & $\begin{array}{l}\text { Tracking and promoting the } \\
\text { usage of a COVID-19 contact } \\
\text { tracing app }\end{array}$ & Germany & $\begin{array}{l}\text { Online panel survey \& mobile } \\
\text { tracking of actual users }\end{array}$ & Intervention study & $\begin{array}{ll}\text { - } & \text { Risk of severe illness } \\
\text { - } & \text { Risk of exposure to COVID-19 } \\
\text { - } & \text { Informative and motivational video } \\
\text { messages } & \text { Monetary incentives }\end{array}$ \\
\hline [55] & $\begin{array}{l}\text { Longitudinal study, } 7 \text { months } \\
\text { (April-November) of public } \\
\text { opinion on technology-based } \\
\text { CT and privacy }\end{array}$ & $\begin{array}{l}\text { Multiple countries, mostly } \\
\text { European and northern } \\
\text { America. }\end{array}$ & $\begin{array}{l}\text { Online survey ( } N=2337 \text { total, } \\
100-200 \text { per survey); Young } \\
\text { adults were recruited from } \\
\text { Prolific (paid sampling) }\end{array}$ & $\begin{array}{l}\text { Longitudinal analysis; } \\
\text { demographic analysis; } \\
\text { qualitative analysis }\end{array}$ & $\begin{array}{l}\text { - } \quad \text { Privacy concern } \\
\text { - } \quad \text { Transparence and oversight } \\
\text { Inaccurate understanding of the } \\
\text { technology }\end{array}$ \\
\hline [56] & $\begin{array}{l}\text { Cross sectional investigation } \\
\text { of the uptake of the CTA in } \\
\text { Australia, the barriers for } \\
\text { downloading the app, and } \\
\text { individuals understanding of } \\
\text { the application. }\end{array}$ & Australia & $\begin{array}{l}\text { Online survey }(N=1500) \\
\text { National representative } \\
\text { sample (excluded those } \\
\text { whose were a health care } \\
\text { professional or had been } \\
\text { tested for COVID-19) }\end{array}$ & Descriptive analysis & $\begin{array}{ll}\text { - } & \text { Age } \\
\text { - } & \text { Privacy concerns } \\
\text { - } & \text { Technical problems } \\
\text { - } & \text { Perceiving app as unnecessary } \\
\text { - } & \text { Distrust in the government } \\
\text { - } & \text { Need more information before deciding } \\
\text { - } & \text { Uncoded miscellaneous reasons (e.g., } \\
\text { apathy and following the decisions of } \\
\text { others) }\end{array}$ \\
\hline
\end{tabular}


Table A1. Cont.

\begin{tabular}{|c|c|c|c|c|c|}
\hline Study & Focus & Context & Sampling & Data Analysis Procedure & Key Factors Associated with Acceptance \\
\hline [57] & $\begin{array}{l}\text { Investigate the uptake of the } \\
\text { CTA in Schweiz, and reasons } \\
\text { against using it. }\end{array}$ & Switzerland & $\begin{array}{l}\text { Online survey }(N=1511) \\
\text { respondents were recruited } \\
\text { fromNationwide } \\
\text { online panel. }\end{array}$ & $\begin{array}{l}\text { Multivariate logistic } \\
\text { regression; descriptive } \\
\text { analysis }\end{array}$ & $\begin{array}{l}\text { - } \quad \text { Sociodemographic factors (household } \\
\text { income, Internet use, adherence to other } \\
\text { preventive recommendations (masks), age, } \\
\text { non-smoking, citizenship status, language } \\
\text { region, education) } \\
\text { - Trust in the health authorities and } \\
\text { government } \\
\text { - Trust in science }\end{array}$ \\
\hline [58] & $\begin{array}{l}\text { Attitudes towards general } \\
\text { quarantine and potential use } \\
\text { and acceptability of CTA }\end{array}$ & France & $\begin{array}{l}\text { Online survey }(N=1849) \\
\text { Representative sample }\end{array}$ & $\begin{array}{l}\text { Logistic and binomial } \\
\text { regression models }\end{array}$ & $\begin{array}{l}\text { - } \quad \text { Perceived individual health threat by } \\
\text { - } \quad \text { Time preferences } \\
\text { - } \quad \text { Trust in the government }\end{array}$ \\
\hline [59] & $\begin{array}{l}\text { The potential uptake of a } \\
\text { contact tracing app in the } \\
\text { Dutch population depending } \\
\text { on the characteristics of } \\
\text { the app }\end{array}$ & Netherlands & $\begin{array}{l}\text { Discrete choice experiment, } \\
\text { online survey }(N=900) \\
\text { Representative sample }\end{array}$ & $\begin{array}{l}\text { Simulated maximum } \\
\text { likelihood methods; } \\
\text { descriptive analysis; mixed } \\
\text { logit model, }\end{array}$ & $\begin{array}{l}\text { - Sociodemographic factors (age and } \\
\text { educational attainment) } \\
\text { - The presence of serious underlying health } \\
\text { - } \quad \text { Sonditions } \\
\text { Stance on COVID-19 infection risks }\end{array}$ \\
\hline [60] & $\begin{array}{l}\text { Investigates drivers and } \\
\text { barriers to the use of CTAs }\end{array}$ & Ireland & $\begin{array}{l}\text { Survey }(N=8088) \text {, } \\
\text { participants above } 18 \text { years } \\
\text { old were recruited by email, } \\
\text { apps, social media and } \\
\text { university webpage }\end{array}$ & $\begin{array}{l}\text { Statistical analysis; weighted } \\
\text { analyses }\end{array}$ & $\begin{array}{l}\text { - To help family and friends and a sense of } \\
\text { responsibility to the community } \\
\text { - Fear of surveillance after the pandemic } \\
\text { from government or technology companies }\end{array}$ \\
\hline [61] & $\begin{array}{l}\text { Attitudes to hypothetical use. } \\
\text { Assessed attitudes towards } \\
\text { three tracking technologies }\end{array}$ & Taiwan region & $\begin{array}{l}\text { Online survey }(N=1087) ; \\
\text { young Taiwanese adults aged } \\
18-25 \text { years. }\end{array}$ & $\begin{array}{l}\text { Descriptive analysis; } \\
\text { bayesian ordinal probit } \\
\text { regression }\end{array}$ & $\begin{array}{ll}\text { - } & \text { Perceived Risk from COVID-19 } \\
\text { - } & \text { Perceived Benefits from Tracking } \\
\text { Perceptions of Tracking Technologies }\end{array}$ \\
\hline
\end{tabular}


Table A1. Cont.

\begin{tabular}{|c|c|c|c|c|c|}
\hline Study & Focus & Context & Sampling & Data Analysis Procedure & Key Factors Associated with Acceptance \\
\hline [62] & $\begin{array}{l}\text { The acceptance of COVID-19 } \\
\text { tracking technologies }\end{array}$ & Poland & $\begin{array}{l}\text { Study 1: online survey via an } \\
\text { online research panel } \\
(N=1046) ; \text { a nationwide } \\
\text { sample with quotas of the } \\
\text { general Polish adult } \\
\text { population (aged } 18-70) \text {. } \\
\text { Study 2: online survey via } \\
\text { Facebook ( } N=1680) ; \text { random } \\
\text { sample recruited through } \\
\text { Facebook encouraged by a } \\
\text { possibility of remuneration } \\
\text { (aged } 18-69)\end{array}$ & $\begin{array}{l}\text { Zero-order correlation; } \\
\text { multiple regression analysis }\end{array}$ & $\begin{array}{ll}\text { - } & \text { Perceived personal threat } \\
\text { - } & \text { Lack of personal control } \\
\text { - } & \text { Age } \\
\text { - } & \text { Gender } \\
\text { - } & \text { Right-wing authoritarianism } \\
\text { - } & \text { Endorsement of liberty } \\
\text { - } & \text { Political views (moral) } \\
\text { - } & \text { Political views (economic) }\end{array}$ \\
\hline [63] & $\begin{array}{l}\text { Compare citizens preferences } \\
\text { for apps with different } \\
\text { privacy designs }\end{array}$ & UK & $\begin{array}{l}2 \text { online survey-based } \\
\text { experiments. Study } 1 \\
(N=1504) \text {, participants from } \\
\text { Dynata online panel of } \\
\text { diverse respondents. } \\
\text { Study } 2(N=809), \text { the sample } \\
\text { from Prolific Academic }\end{array}$ & $\begin{array}{l}\text { Descriptive analysis; } \\
\text { treatment and moderator } \\
\text { effect analysis }\end{array}$ & $\begin{array}{l}\text { Trust in the national public health } \\
\text { service system } \\
\text { - Satisfaction with the government's } \\
\text { handling of coronavirus } \\
\text { - Concerns about data privacy and security }\end{array}$ \\
\hline [64] & $\begin{array}{l}\text { Motivators of intended } \\
\text { contact tracing uptake }\end{array}$ & Australia and U.S. & $\begin{array}{l}\text { Online scenario-based survey } \\
\text { (Australia, } N=1117 \text {; U.S., } \\
N=888 \text { ); Adults recruited by } \\
\text { Professional panel/ survey } \\
\text { companies }\end{array}$ & $\begin{array}{l}\text { Descriptive analysis; } \\
\text { correlation analysis; factorial } \\
\text { analysis of covariance } \\
\text { (ANCOVA) }\end{array}$ & $\begin{array}{ll}- & \text { Message framing } \\
- & \text { Information safety } \\
\text { - } & \text { political affiliation }\end{array}$ \\
\hline
\end{tabular}




\section{References}

1. Riemer, K.; Ciriello, R.; Peter, S.; Schlagwein, D. Digital contact-tracing adoption in the COVID-19 pandemic: IT governance for collective action at the societal level. Eur. J. Inf. Syst. 2020. [CrossRef]

2. Sun, K.; Viboud, C. Impact of contact tracing on SARS-CoV-2 transmission. Lancet Infect. Dis. 2020, 20, 876-877. [CrossRef]

3. Osman, M.; Fenton, N.E.; Mclachlan, S.; Lucas, P.; Dube, K.; Hitman, G.A.; Kyrimi, E.; Neil, M. The Thorny Problems of Covid-19 Contact Tracing Apps: The Need for a Holistic Approach. J. Behav. Econ. Policy 2020, 4, 43-59.

4. Sturniolo, S.; Waites, W.; Colbourn, T.; Manheim, D.; Panovska-Griffiths, J. Testing, Tracing and isolation in compartmental models. PLoS Comput. Biol. 2021, 17, e1008633. [CrossRef]

5. Fetzer, T.; Graeber, T. Does Contact Tracing Work? Quasi-Experimental Evidence from an Excel Error in England. Available online: https: / / ssrn.com/abstract=3753893 (accessed on 23 December 2020).

6. Toussaert, S. Upping uptake of COVID contact tracing apps. Nat. Hum. Behav. 2021, 5, 183-184. [CrossRef]

7. Walrave, M.; Waeterloos, C.; Ponnet, K. Adoption of a Contact Tracing App for Containing COVID-19: A Health Belief Model Approach. JMIR Public Heal. Surveill. 2020, 6, e20572. [CrossRef]

8. Yasaka, T.M.; Lehrich, B.M.; Sahyouni, R. Peer-to-peer contact tracing: Development of a privacy-preserving smartphone app. JMIR mHealth uHealth 2020, 8, e18936. [CrossRef]

9. European Commision. How Tracing and Warning Apps Can Help during the Pandemic. Available online: https: / / ec.europa.eu/info/live-work-travel-eu/coronavirus-response/travel-during-coronavirus-pandemic/how-tracing-andwarning-apps-can-help-during-pandemic_en (accessed on 19 October 2020).

10. Sharon, T. Blind-sided by privacy? Digital contact tracing, the Apple/Google API and big tech's newfound role as global health policy makers. Ethics Inf. Technol. 2020, 1-13. [CrossRef] [PubMed]

11. Sowmiya, B.; Abhijith, V.S.; Sudersan, S.; Sakthi Jaya Sundar, R.; Thangavel, M.; Varalakshmi, P. A Survey on Security and Privacy Issues in Contact Tracing Application of Covid-19. SN Comput. Sci. 2021, 2, 1-11. [CrossRef] [PubMed]

12. Juneidi, S.J. Covid-19 Tracing Contacts Apps: Technical and Privacy Issues. Int. J. Adv. Soft Comput. Appl. 2020, 12, 25-44.

13. Zeinalipour-Yazti, D.; Claramunt, C. COVID-19 Mobile Contact Tracing Apps (MCTA): A Digital Vaccine or a Privacy Demolition? In Proceedings of the 2020 21st IEEE International Conference on Mobile Data Management (MDM), Versailles, France, 30 June-3 July 2020.

14. Ferretti, L.; Wymant, C.; Kendall, M.; Zhao, L.; Nurtay, A.; Abeler-Dörner, L.; Parker, M.; Bonsall, D.; Fraser, C. Quantifying SARS-CoV-2 transmission suggests epidemic control with digital contact tracing. Science 2020, 368, 1-7. [CrossRef]

15. Azad, M.A.; Arshad, J.; Akmal, A.; Abdullah, S.; Ahmad, F.; Imran, M.; Riaz, F. A First Look at Privacy Analysis of COVID-19 Contact Tracing Mobile Applications. IEEE Internet Things J. 2020. [CrossRef]

16. Currie, D.J.; Peng, C.Q.; Lyle, D.M.; Jameson, B.A.; Frommer, M.S. Stemming the flow: How much can the Australian smartphone app help to control COVID-19? Public Health Res. Pract. 2020, 30, 3022009. [CrossRef]

17. Nature Editorial Show evidence that apps for COVID-19 contact-tracing are secure and effective. Nature 2020, 580, 563. [CrossRef] [PubMed]

18. Rowe, F.; Ngwenyama, O.; Richet, J.L. Contact-tracing apps and alienation in the age of COVID-19. Eur. J. Inf. Syst. 2020, 29, 545-562. [CrossRef]

19. Abbas, R.; Michael, K. IEEE Consumer Electronics Magazine; Institute of Electrical and Electronics Engineers Inc.: Piscataway, NJ, USA, September 2020; pp. 65-70.

20. Magklaras, G.; López-Bojórquez, L.N. A Review of Information Security Aspects of the Emerging Covid-19 Contact Tracing Mobile Phone Applications. In Human Aspects of Information Security and Assurance; Clarke, N., Furnell, S., Eds.; IFIP Advances in Information and Communication Technology; Springer International Publishing: Basel, Switzerland, 2020; Volume 593, pp. 30-44, ISBN 9783030574031.

21. Abeler, J.; Bäcker, M.; Buermeyer, U.; Zillessen, H. Covid-19 contact tracing and data protection can go together. JMIR $m$ Health uHealth 2020, 8, e19359. [CrossRef] [PubMed]

22. Fahey, R.A.; Hino, A. COVID-19, Digital privacy, and the social limits on data-focused public health responses. Int. J. Inf. Manag. 2020, 55, 102181. [CrossRef]

23. Bengio, Y.; Janda, R.; Yu, Y.W.; Ippolito, D.; Jarvie, M.; Pilat, D.; Struck, B.; Krastev, S.; Sharma, A. The need for privacy with public digital contact tracing during the COVID-19 pandemic. Lancet Digit. Heal. 2020, 2, e342-e344. [CrossRef]

24. Morley, J.; Cowls, J.; Taddeo, M.; Floridi, L. Ethical guidelines for COVID-19 tracing apps. Nature 2020, 582, 29-31. [CrossRef]

25. Walrave, M.; Waeterloos, C.; Ponnet, K. Ready or Not for Contact Tracing? Investigating the Adoption Intention of COVID-19 Contact-Tracing Technology Using an Extended Unified Theory of Acceptance and Use of Technology Model. Cyberpsychol. Behav. Soc. Netw. 2020, 1-7. [CrossRef]

26. Bedford, J.; Enria, D.; Giesecke, J.; Heymann, D.L.; Ihekweazu, C.; Kobinger, G.; Lane, H.C.; Memish, Z.; don Oh, M.; Sall, A.A.; et al. COVID-19: Towards controlling of a pandemic. Lancet 2020, 395, 1015-1018. [CrossRef]

27. Megnin-Viggars, O.; Carter, P.; Melendez-Torres, G.J.; Weston, D.; Rubin, G.J. Facilitators and barriers to engagement with contact tracing during infectious disease outbreaks: A rapid review of the evidence. PLoS ONE 2020, 15. [CrossRef] [PubMed] 
28. Altmann, S.; Milsom, L.; Zillessen, H.; Blasone, R.; Gerdon, F.; Bach, R.; Kreuter, F.; Nosenzo, D.; Toussaert, S.; Abeler, J. Acceptability of App-Based Contact Tracing for COVID-19: Cross-Country Survey Study. JMIR mHealth uHealth 2020, 8, e19857. [CrossRef] [PubMed]

29. Kostka, G.; Habich-Sobiegalla, S. In Times of Crisis: Public Perceptions Towards COVID-19 Contact Tracing Apps in China, Germany and the US. SSRN Electron. J. 2020. [CrossRef]

30. Ekong, I.; Chukwu, E.; Chukwu, M. COVID-19 mobile positioning data contact tracing and patient privacy regulations: Exploratory search of global response strategies and the use of digital tools in Nigeria. JMIR mHealth uHealth 2020, 8, e19139. [CrossRef]

31. Mandavilli, A. The Coronavirus is Mutating. What Does That Mean for Us? The New York Times: New York, NY, USA, 2020.

32. Callaway, E. The coronavirus is mutating-Does it matter? Nature 2020, 585, 174-177. [CrossRef]

33. Trang, S.; Trenz, M.; Weiger, W.H.; Tarafdar, M.; Cheung, C.M.K. One app to trace them all? Examining app specifications for mass acceptance of contact-tracing apps. Eur. J. Inf. Syst. 2020, 29, 415-428. [CrossRef]

34. Kofler, N.; Baylis, F. Ten reasons why immunity passports are a bad idea. Nature 2020, 581, 379-381. [CrossRef]

35. Dye, C.; Mills, M.C. COVID-19 vaccination passports. Science 2021, 371, 1184. [CrossRef]

36. European Commission Coronavirus: Commission Proposes a Digital Green Certificate. Available online: https: / / ec.europa.eu/ commission/presscorner/detail/en/IP_21_1181 (accessed on 2 June 2021).

37. Schwarz, A.; Chin, W. Looking forward: Toward an understanding of the nature and definition of IT acceptance. J. Assoc. Inf. Syst. 2007, 8, 230-243. [CrossRef]

38. Arksey, H.; O'Malley, L. Scoping studies: Towards a methodological framework. Int. J. Soc. Res. Methodol. Theory Pract. 2005, 8, 19-32. [CrossRef]

39. Levac, D.; Colquhoun, H.; O’Brien, K.K. Scoping studies: Advancing the methodology. Implement. Sci. 2010, 5, 1-9. [CrossRef]

40. Colquhoun, H.L.; Levac, D.; O’Brien, K.K.; Straus, S.; Tricco, A.C.; Perrier, L.; Kastner, M.; Moher, D. Scoping reviews: Time for clarity in definition, methods, and reporting. J. Clin. Epidemiol. 2014, 67, 1291-1294. [CrossRef] [PubMed]

41. Munn, Z.; Peters, M.D.J.; Stern, C.; Tufanaru, C.; McArthur, A.; Aromataris, E. Systematic review or scoping review? Guidance for authors when choosing between a systematic or scoping review approach. BMC Med. Res. Methodol. 2018, 18, 1-7. [CrossRef] [PubMed]

42. Anderson, S.; Allen, P.; Peckham, S.; Goodwin, N. Asking the right questions: Scoping studies in the commissioning of research on the organisation and delivery of health services. Heal. Res. Policy Syst. 2008, 6. [CrossRef]

43. Aksnes, D.W.; Sivertsen, G. A criteria-based assessment of the coverage of scopus and web of science. J. Data Inf. Sci. 2019, 4, 1-21. [CrossRef]

44. Dixon-Woods, M.; Agarwal, S.; Jones, D.; Young, B.; Sutton, A. Synthesising qualitative and quantitative evidence: A review of possible methods. J. Heal. Serv. Res. Policy 2005, 10, 45-53. [CrossRef] [PubMed]

45. Ahmad, M.; Iram, K.; Jabeen, G. Perception-based influence factors of intention to adopt COVID-19 epidemic prevention in China. Environ. Res. 2020, 190, 109995. [CrossRef]

46. Sharma, S.; Singh, G.; Sharma, R.; Jones, P.; Kraus, S.; Dwivedi, Y.K. Digital Health Innovation: Exploring Adoption of COVID-19 Digital Contact Tracing Apps. IEEE Trans. Eng. Manag. 2020. [CrossRef]

47. Kaspar, K. Motivations for social distancing and app use as complementary measures to combat the COVID-19 pandemic: Quantitative survey study. J. Med. Internet Res. 2020, 22. [CrossRef]

48. Suh, A.; Li, M. Digital tracing during the COVID-19 pandemic: User appraisal, emotion, and continuance intention. Sustainability 2021, 13, 608. [CrossRef]

49. Li, T.; Cobb, C.; Yang, J.; Baviskar, S.; Agarwal, Y.; Li, B.; Bauer, L.; Hong, J.I. What makes people install a COVID-19 contact-tracing app? Understanding the influence of app design and individual difference on contact-tracing app adoption intention. arXiv 2020, arXiv:2012.12415.

50. Williams, S.N.; Armitage, C.J.; Tampe, T.; Dienes, K. Public attitudes towards COVID-19 contact tracing apps: A UK-based focus group study. Heal. Expect. 2021, 24, 377-385. [CrossRef] [PubMed]

51. Zimmermann, B.M.; Fiske, A.; Prainsack, B.; Hangel, N.; McLennan, S.; Buyx, A. Early perceptions of COVID-19 contact tracing apps in German-speaking countries: Comparative mixed methods study. J. Med. Internet Res. 2021, 23, e25525. [CrossRef]

52. Abuhammad, S.; Khabour, O.F.; Alzoubi, K.H. Covid-19 contact-tracing technology: Acceptability and ethical issues of use. Patient Prefer. Adherence 2020, 14, 1639-1647. [CrossRef] [PubMed]

53. Garrett, P.M.; White, J.P.; Lewandowsky, S.; Kashima, Y.; Perfors, A.; Little, D.R.; Geard, N.; Mitchell, L.; Tomko, M.; Dennis, S. The acceptability and uptake of smartphone tracking for COVID-19 in Australia. PLoS ONE 2021, 16, e0244827. [CrossRef]

54. Munzert, S.; Selb, P.; Gohdes, A.; Stoetzer, L.F.; Lowe, W. Tracking and promoting the usage of a COVID-19 contact tracing app. Nat. Hum. Behav. 2021, 5, 247-255. [CrossRef]

55. Simko, L.; Chang, J.L.; Jiang, M.; Calo, R.; Roesner, F.; Kohno, T. COVID-19 Contact Tracing and Privacy: A Longitudinal Study of Public Opinion. Available online: https:/ / arxiv.org/pdf/2012.01553.pdf (accessed on 4 December 2020).

56. Thomas, R.; Michaleff, Z.A.; Greenwood, H.; Abukmail, E.; Glasziou, P. Concerns and misconceptions about the australian government's COVIDsafe app: Cross-sectional survey study. JMIR Public Health Surveill. 2020, 6, e23081. [CrossRef] 
57. von Wyl, V.; Höglinger, M.; Sieber, C.; Kaufmann, M.; Moser, A.; Serra-Burriel, M.; Ballouz, T.; Menges, D.; Frei, A.; Puhan, M.A. Drivers of acceptance of COVID-19 proximity tracing apps in Switzerland: Panel survey analysis. JMIR Public Health Surveill. 2021, 7, e25701. [CrossRef] [PubMed]

58. Guillon, M.; Kergall, P. Attitudes and opinions on quarantine and support for a contact-tracing application in France during the COVID-19 outbreak. Public Health 2020, 188, 21-31. [CrossRef] [PubMed]

59. Jonker, M.; de Bekker-Grob, E.; Veldwijk, J.; Goossens, L.; Bour, S.; Rutten-Van Mölken, M. COVID-19 Contact Tracing Apps: Predicted Uptake in the Netherlands Based on a Discrete Choice Experiment. JMIR mHealth uHealth 2020, 8, e20741. [CrossRef] [PubMed]

60. O'Callaghan, M.E.; Buckley, J.; Fitzgerald, B.; Johnson, K.; Laffey, J.; McNicholas, B.; Nuseibeh, B.; O’Keeffe, D.; O’Keeffe, I.; Razzaq, A.; et al. A national survey of attitudes to COVID-19 digital contact tracing in the Republic of Ireland. Irish J. Med. Sci. 2020, 1-25. [CrossRef]

61. Garrett, P.M.; Wang, Y.; White, J.P.; Hsieh, S.; Strong, C.; Lee, Y.C.; Lewandowsky, S.; Dennis, S.; Yang, C.T. Young adults view smartphone tracking technologies for covid-19 as acceptable: The case of taiwan. Int. J. Environ. Res. Public Health 2021, 18, 1332. [CrossRef] [PubMed]

62. Wnuk, A.; Oleksy, T.; Maison, D. The acceptance of Covid-19 tracking technologies: The role of perceived threat, lack of control, and ideological beliefs. PLOS ONE 2020, 15, e0238973. [CrossRef]

63. Horvath, L.; Banducci, S.; James, O. Citizens' Attitudes to Contact Tracing Apps. J. Exp. Polit. Sci. 2020, 1-13. [CrossRef]

64. Bradshaw, E.L.; Ryan, R.M.; Noetel, M.; Saeri, A.K.; Slattery, P.; Grundy, E.; Calvo, R. Information Safety Assurances Increase Intentions to Use COVID-19 Contact Tracing Applications, Regardless of Autonomy-Supportive or Controlling Message Framing. Front. Psychol. 2021, 11, 3772. [CrossRef]

65. Bish, A.; Michie, S. Demographic and attitudinal determinants of protective behaviours during a pandemic: A review. Br. J. Health Psychol. 2010, 15, 797-824. [CrossRef] [PubMed]

66. Crawshaw, A.F.; Deal, A.; Rustage, K.; Forster, A.S.; Campos-Matos, I.; Vandrevala, T.; Würz, A.; Pharris, A.; Suk, J.; Kinsman, J.; et al. What must be done to tackle vaccine hesitancy and barriers to COVID-19 vaccination in migrants? J. Travel Med. 2021, 1-4. [CrossRef]

67. Strecher, V.J.; Rosenstock, I.M. The Health Belief Model. In Cambridge Handbook of Psychology, Health and Medicine, Second Edition; Baum, A., Newman, S., Weinman, J., West, R., McManus, C., Eds.; Cambridge University Press: Cambridge, UK, 1997; pp. 97-102, ISBN 9780511543579.

68. Venkatesh, V.; Morris, M.G.; Davis, G.B.; Davis, F.D. User acceptance of information technology: Toward a unified view. MIS Q 2003, 27, 425-478. [CrossRef]

69. Bagozzi, R.P.; Davis, F.D.; Warshaw, R.P. Development and Test of a Theory of Technological Learning and Usage. Hum. Relat. 1992, 45, 659-686. [CrossRef] 